\section{$\underset{\substack{\text { hommes } \\ \text { \& migrations }}}{ }$}

\section{Hommes \& migrations}

Revue française de référence sur les dynamiques

migratoires

\section{$1284 \mid 2010$}

Migrations et environnement

\title{
Tête de Turc
}

Film français de Pascal Elbé

\section{André Videau}

\section{Q OpenEdition \\ 1 Journals}

\section{Édition électronique}

URL : http://journals.openedition.org/hommesmigrations/1274

DOI : 10.4000/hommesmigrations. 1274

ISSN : 2262-3353

\section{Éditeur}

Musée national de l'histoire de l'immigration

\section{Édition imprimée}

Date de publication : 1 mars 2010

Pagination : 198

ISSN : 1142-852X

\section{Référence électronique}

André Videau, «Tête de Turc », Hommes \& migrations [En ligne], 1284 | 2010, mis en ligne le 29 mai

2013, consulté le 22 septembre 2020. URL : http://journals.openedition.org/hommesmigrations/1274

; DOI : https://doi.org/10.4000/hommesmigrations.1274

Ce document a été généré automatiquement le 22 septembre 2020.

Tous droits réservés 


\title{
Tête de Turc
}

\author{
Film français de Pascal Elbé
}

\section{André Videau}

1 Le polar de banlieue, à plus ou moins fortes connotations sociales, est un genre qui fait les beaux soirs des chaînes de télévision publiques ou privées. La concurrence est rude et le risque est grand d'accumuler les clichés pour satisfaire le plus grand nombre. À l'inverse on peut considérer qu'un sujet rebattu, plus qu'un clone commercial, constitue un bon exercice de style, une sorte d'examen de passage pour débutant. D'autant que les moyens mis à disposition sont considérables, si on les compare à une série télévisée "ordinaire".

2 Le comédien Pascal Elbé tenté par la mise en scène, n'a pas brûlé les étapes. Il a au préalable collaboré à plusieurs scénarios, dont celui de La mauvaise foi écrit avec son ami et complice Roschdy Zem (voir H\&M 1264, nov.-déc 2006).

3 La soirée sera chaude sans que rien ne prédispose plus particulièrement à la violence.

4 La voiture d'un toubib urgentiste s'immobilise sous les jets de pierre des loubards du quartier qui prennent la fuite. Simon est grièvement atteint. Bora reste sur place, un temps frappé de stupeur...

5 Le face-à-face inexpugnable entre beurs/blacks des cités et flics (avec leurs codes opérationnels) se trouvera modifié par l'entremise des Arméniens, moins prévisibles dans leur comportement, malgré des références similaires (l'honneur, l'omertà au sein de la cité, le poids de la famille, la prépondérance du chef de clan - l'indispensable et emblématique Simon Abkarian). Autre différence - de taille - le responsable du dérapage qui va dramatiser la situation n'est pas l'un des deux héros, têtes d'affiche et frères antagonistes, Roschdy Zem et Pascal Elbé, mais Bora (Samir Makhlouf comédien débutant, très prometteur), le petit frère de 14 ans. Sa jeunesse entre soumission et rébellion, va aggraver son cas de conscience. Il ne saurait rester le spectateur passif d'un caillassage, le petit voyou qui après l'agression collective jette un cocktail molotov, le "fils à maman" transformant sa lâcheté en bravoure pour sauver un homme dont il a mis la vie en péril et recevoir une médaille en récompense de sa traîtrise. 
6 Quant aux femmes, elles jouent aussi une partition hors des conventions habituelles : dans des notes modérées pour Florence Thomassin et Valérie Benguigui, avec tout l'éclat de la mère méditerranéenne pour Ronit Elkabetz.

7 Le coup d'essai est presque un coup de maître et le résultat est un thriller nerveux, sans pathos et habilement décentré par rapport aux cibles habituelles et qui, de l'avis de l'auteur, trouve ses modèles du côté de Martin Scorsese ou de James Gray. 